AMERICAN JOURNAL OF SOCIAL AND MANAGEMENT SCIENCES

ISSN Print: 2156-1540, ISSN Online: 2151-1559, doi:10.5251/ajsms.2010.1.1.13.23

(C) 2010, ScienceHuß, http://www.scihub.org/AJSMS

\title{
Speculation, futures prices, and the US real price of crude oil
}

\author{
Lonnie K. Stevans and David N. Sessions \\ Frank G. Zarb School of Business, Department of IT/QM \\ Hofstra University Hempstead, NY 11549
}

\begin{abstract}
In this study, we examine the relationship between the U.S. real price of oil and factors that affect its movement over time: futures prices, the value of the dollar, exploration, demand, and supply. All of these variables are treated as jointly endogenous and a reduced form vector error correction model, testing for cointegration amongst the variables, is estimated. We find that for model specifications with short-term futures contracts, supply does indeed dominate price movements in the crude oil market. However, for specifications including longer-term contracts that are inherently more speculative, the real price of oil appears to be determined predominantly by the futures price. Moreover, there is empirical evidence of hoarding in the crude oil market: both oil stocks/inventories and futures prices are found to be positively cointegrated with each other. From a policy perspective, the results of this analysis indicate that if regulators really wanted to limit speculation in the oil market, they should keep the shorter-term futures contracts and eliminate the more speculative six months futures contracts.
\end{abstract}

Keywords: futures prices, cointegration, speculation, hoarding

\section{INTRODUCTION}

There are those who believe high oil prices are the result of market forces--limited supply meets endless demand, which makes barrels of crude more expensive. In an October 2004 National Review article, "The Oil Bubble: Set to Burst?" it was argued that oil prices, at that time $\$ 62$ a barrel, would soon collapse. In ten months, oil was $\$ 73$ a barrel. ${ }^{i}$ All through oil's five-year price surge, rising to $\$ 105$ per barrel as of March 2008, there have been many voices asserting that the precipitous rise is all the result of speculation--unsupported by the rudiments of supply and demand. i. Speculation will increase oil prices through hoarding or increasing private inventories of crude. Some espouse that inventories have remained at "normal" levels, which implies that the rise in oil prices is not the result of runaway speculation, but the consequence of decreasing supply and the rapid growth of developing economies like China and India."il We would like to point out that the notion of high futures prices reducing physical supplies through "hoarding" has nothing to do with a "normal" level of inventories, but whether there exists a positive relationship between futures prices and oil stocks/inventories.

In this study, the relationship between the price of oil and factors that affect its movement over time: futures prices, the value of the dollar, exploration, world demand, and world supply, will be examined. We will treat all of these variables as jointly endogenous and estimate a reduced form VEC model, testing for cointegration amongst the variables. The advantage to using this approach is twofold: first, the statistical results we get are not subject to endogeneity bias, since the models used have only predetermined or exogenous variables on the right-hand side. Second, given that we will test for cointegrating relationships, there is little concern about finding "spurious" associations among the variables that may exist when one simply correlates two or more random walks with each other (Enders (2004)). Our fundamental purpose will be to determine just how much influence futures prices/speculation has on the real spot price of oil in the long-run.

\section{THEORY}

Commodity-index investing has increased to $\$ 260$ billion in 2008 from $\$ 13$ billion in 2003 . The prices of the 25 commodities that make up key market indexes have increased by an average of 183 percent in the same period. ${ }^{\text {iv }}$ Index-fund investors do not buy physical commodities--they trade in futures contracts which are agreements to buy or sell a specific amount of a commodity at a set price by a specific date. $^{\vee} \quad$ Thus, futures are benchmarks for prices across commodities markets. ${ }^{\text {vi }}$ An oil refiner may use futures to ensure up a quantity of oil for delivery at a 
later date or a farmer may use them to guarantee a price for his crop, but an index fund investor is only interested in riding a price trend by trading in contracts. vii These investors in the fund are not financing new oil wells that could boost global crude supplies-they are just reaping price gains in the commodity markets. ${ }^{\text {viii }}$ Crude oil was at $\$ 54$ per barrel in January 2007, $\$ 72$ in August 2007, and $\$ 105$ in March 2008. ${ }^{\text {ix }}$ Many believe that oil prices are set based upon rumor, greed, and the fear of world interruptions-all having little to do with physical supply and demand.

What about the argument that oil price fluctuations are predominantly due to changes in demand and supply? Since early 2007, the U.S. demand for petroleum has fallen by one (1) percent and world demand has risen by 1.3 percent. Testifying to a U.S. Congressional Committee, Cambridge Energy Research Associates (CERA) has stated that world supplies are up and world oil production will increase significantly over the next seven years. ${ }^{x}$ Moreover, an analysis of global oil production and development demonstrates that the world is not running out of oil in the near-term, and a large increase in the availability of unconventional oils will expand global liquid hydrocarbons capacity by as much as one-fourth in the next ten years. ${ }^{\text {xi }}$ Oil has always been produced under conditions of imperfect competition. From the late nineteenth century days of John D. Rockefeller and the Standard Oil monopoly to the emergence of the "Seven Sisters" oligopoly--encompassing Standard Oil, Shell, BP, Texaco, Mobil, Gulf and Socal, to the rise of OPEC representing the major producing countries, the notion of a "free market" in the production of oil has been a delusion. One could argue that the predominant determinant of price has shifted from OPEC (having only $40 \%$ of the world production) and the oil companies to the speculators in the commodities markets. What transpires in the unregulated New York Mercantile Exchange (NYMEX), without the Commodity Futures Trading Commission (CFTC) enforced margin requirements, may be the source of increasing oil prices. Thus, the current market price may not be based solely upon physical supply and demand.

Alternatively, Krugman (2008) and other economists believe that there is no such thing as an "oil bubble." He considers a scenario in which supply and demand balanced at a price of $\$ 25$ per barrel, and speculation drove the price up to $\$ 100$. What would occur? Drivers would cut back on driving, homeowners would turn down their thermostats, and owners of marginal oil wells would put them back into production. As a result, the balance between supply and demand would be replaced with a situation in which supply exceeded demand. This excess supply would drive prices back down--unless the excess was taken off the market. Thus, the only way speculation can increase oil prices is through hoarding. Krugman (2008) does not believe that speculation is prevalent in the market. He maintains that all through the period of the alleged bubble, inventories have remained at more or less normal levels. Therefore, the rise in oil prices is not the result of runaway speculation but rather the result of fundamental factors like the difficulty of finding oil and the rapid growth of emerging economies like China. As mentioned previously, the problem we have with this approach is the fact that the idea of speculation and high futures prices reducing physical supplies through "hoarding" has nothing really to do with what is considered "normal" inventories, but whether increases/decreases in futures prices are associated with increases/decreases in oil stocks or inventories.

As mentioned previously, our purpose here will be to determine just how much of an influence speculation has had on the market price of oil. The time period used is from January 1988 to March 2008. The following variables will be utilized in this analysis,

- $\quad \mathrm{POIL}_{t}$ - Crude Oil Spot Price at Cushing, Oklahoma (adjusted for inflation using the Personal Consumption Expenditure Chain Price Index),

- FPOIL $_{i t}$ - Two, Three, Four, and Six Months Futures Price of Light, Sweet Crude Oil $(i=2,3,4,6)$,

- $\quad E X_{t}$ - Real Trade Weighted Exchange Value of Dollar versus Major Currencies,

- $\quad W E L L S_{t}$ - Total Oil from New U.S. Wells,

- $\quad$ DOIL $_{t}$ - World Oil Demand,

- $\quad S O I L_{t}$ - World Oil Supply, and

- $\quad I R A Q_{t}$ - a Dummy Variable Indicating the Time Periods of the Gulf War and the Iraq War. 
Time plots of the continuous variables may be found in Figure 1. All variables (except the dummy) are expressed in natural logarithmic units, so the estimated coefficients are interpreted as elasticities. The price of petroleum is generally measured as the spot price of either WTI/Light Crude, traded on the New York Mercantile Exchange (NYMEX) for delivery in Cushing, Oklahoma or the price of Brent as traded on the Intercontinental Exchange (ICE, into which the International Petroleum Exchange has been incorporated) for delivery at Sullom Voe. We decided to use the Spot Price at Cushing, Oklahoma, since it has historically been more of a U.S. crude oil "basket." Not only is it used as the basis for U.S.- traded oil futures, but it's also a key benchmark for U.S. production. The two, three, four, and six month's contract settlement prices are the futures prices. The dummy variable is used in an attempt to capture periods in which there were supply interruptions, e.g., Iraq's oil production is 900,000 barrels per day below prewar levels. Inclusion of this variable may be considered to be somewhat controversial, as one can identify many such "structural changes" over the past ten or so years. While this is case, we decided to include just the periods of the Gulf and Iraq wars since these are probably the most mentioned regarding their effects on the price of crude.
Real Price of Oil (Cushing, \$/Bbl)

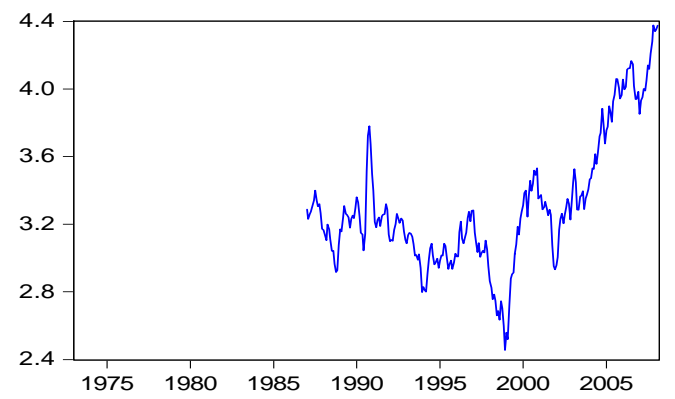

Wells Drilled in U.S., Total Oil

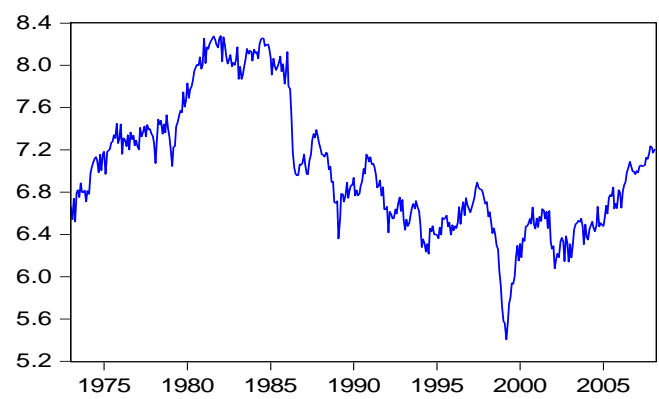

Total World Oil Supply (Mil. b/d)

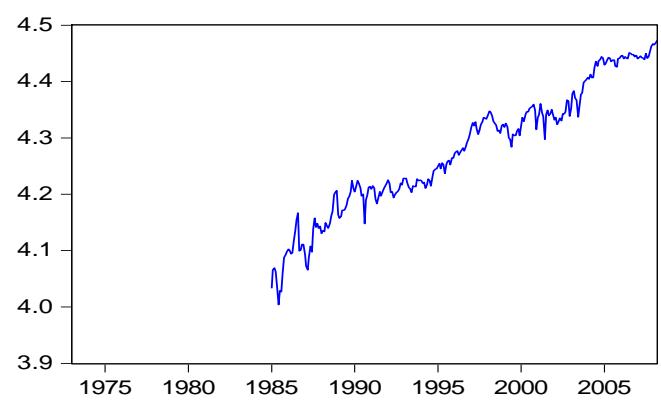

Real Trade-Weighted Exchange Value of U.S.\$ vs. Major Currencies (March 73=100)

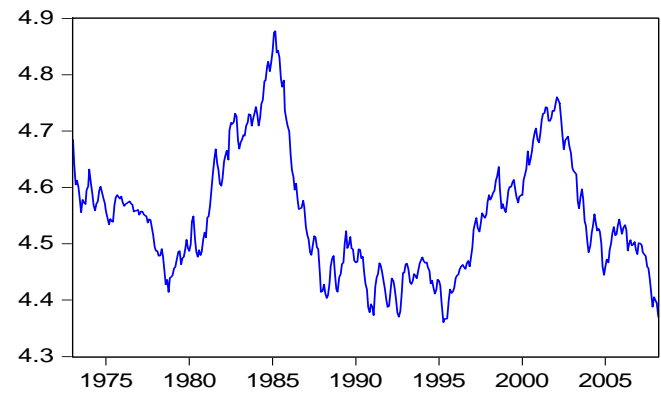

Total World Oil Demand (Mil. b/d)

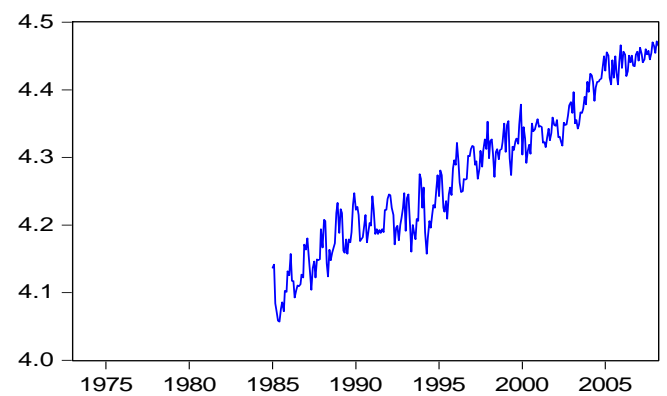


Am. J. Soc. Mgmt. Sci., 2010, 1(1): 13-23

Figure 2

Real Price of Oil vs. Futures Prices

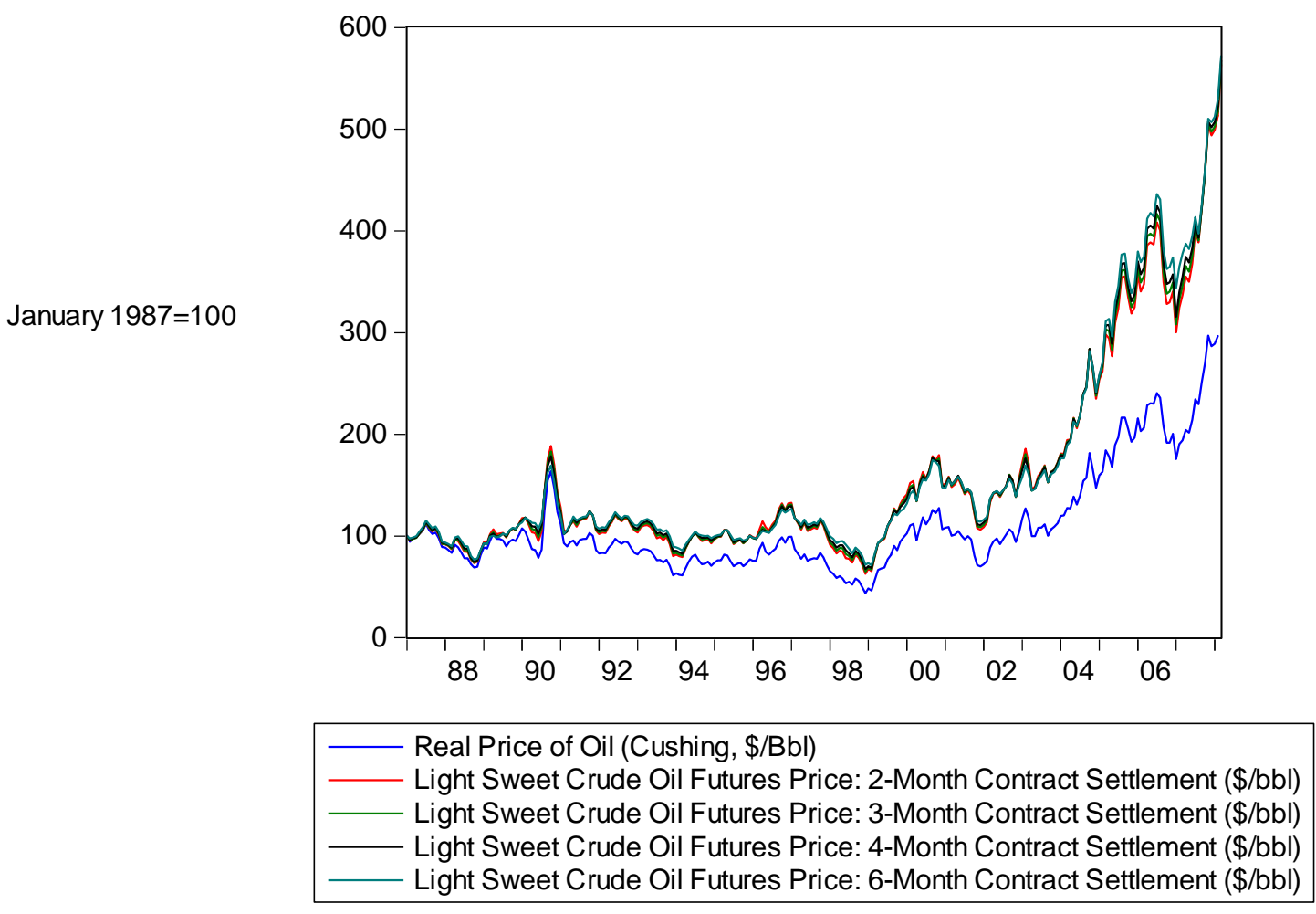

We begin by specifying four separate reduced-form Vector Autoregressive (VAR) model using the above jointly endogenous variables,

$\stackrel{\mathrm{v}}{X}_{i t}=A_{11} \stackrel{\mathrm{v}}{X}_{i t-1}+A_{22} \stackrel{\mathrm{v}}{X}_{i t-2}+\ldots .+A_{p p} \stackrel{\mathrm{v}}{X}_{i t-p}+\stackrel{\mathrm{v}}{\varepsilon_{i t}}$,

where,

$\check{X}_{i t}^{\prime}=\left(\text { POIL }_{t}, F P O I L i_{t}, E X_{t}, W E L L S_{t}, \text { DOIL }, \text { SOIL }, I R A Q_{t}\right)^{\prime}, i=2,3,4,6$,

$A_{i j}-7 \times 7$ matrix of coefficients, $i=2,3,4,6, j=1,2, \ldots, p$, and

$v_{i t}-7 \times 1$ vector of random errors with variance-covariance matrix $\Sigma_{\varepsilon}$.

Using a simple transformation, the VAR in equation (1) can be rewritten in terms of first differences, creating a Vector Error Correction (VEC) model,

$\Delta \stackrel{\mathrm{V}}{i t}_{i t}=\pi_{i} \mathrm{X}_{i t-1}+\sum_{\varpi=1}^{p-1} \pi_{i \varpi} \Delta X_{i t-\varpi}+\stackrel{\mathrm{V}}{\varepsilon}_{i t}$

Alternatively, we can consider a VEC model with a deterministic term. The deterministic term, $D_{t}$, can contain a constant, a linear trend, seasonal dummy variables, or nonstochastic regressors,

$$
\begin{aligned}
& \Delta X_{i t}^{\mathrm{V}}=\pi_{i} X_{i t-1}^{\mathrm{V}}+\sum_{\varpi=1}^{p-1} \pi_{i \varpi} \Delta X_{i t-\sigma}^{\mathrm{V}}+A D_{t}+\stackrel{\mathrm{V}}{i t} . \\
& \pi_{i}=\alpha_{i} \beta_{i}^{\prime}
\end{aligned}
$$

Since the data is monthly and has not been seasonally adjusted, $D_{t}$ will contain monthly seasonal dummy variables.

If the matrix has a full rank $(r=7)$, all components of $\stackrel{\mathrm{v}}{X}_{t}$ are $\mathrm{I}(0)$ (stationary or integrated of order zero). On the other hand, $\stackrel{\mathrm{v}}{X}_{t}$ are stationary in first differences if the $\operatorname{rank}\left(\pi_{i}\right)=0$. If the rank of the matrix is $r<7$, there are $(7-r)$ linear combinations that are nonstationary and $r$ stationary cointegrating relations. Note that the linearly independent vector, 
$\beta_{i}^{\prime} \stackrel{\mathrm{X}}{X}_{i t}$, is stationary and this transformation is not unique unless $r=1$. $\quad \beta$ is the matrix of cointegrating parameters and $\alpha$ is the matrix of weights with which each cointegrating vector enters the six equations of the VEC. $\alpha$ can also be considered as the matrix of the speed of adjustment parameters.

Our interest lies with the unique case where $r=1$. $\beta^{\prime} X_{i t}$ may be written as,

$$
\begin{aligned}
v_{i t}= & \beta_{i 1}+\beta_{i 2} \text { POIL }_{t}+\beta_{i 3} \text { FPOIL }_{i t}+\beta_{i 4} E X_{t}+\beta_{i 5} \text { WELLS }_{t} \\
& +\beta_{i 6} \mathrm{DOIL}_{t}+\beta_{i 7} \mathrm{SOIL}_{t}+\beta_{i 8} I_{i 8} Q_{t}
\end{aligned}
$$

One motivation for the VEC form is to consider $v_{i}=\beta^{\prime} X_{i t}^{\mathrm{v}}$ as defining the underlying economic relations and assume that the agents react to the disequilibrium error $v_{i}$ through the adjustment coefficient $\alpha_{i}$ to restore equilibrium ( $\left.v_{i}=0\right)$; that is, they satisfy the economic relations. The econometric use of the term "equilibrium" is any long-run relationship among nonstationary variables. Cointegration does not require that the long-run relationship be generated by market forces or by the behavioral rules of individuals. In Engle and Granger's (1987) use of the term, the equilibrium relationship may be causal, behavioral, or simply a reduced form relationship among similarly trending variables (Enders (2004)). The cointegrating vector, $\beta_{i}$, is sometimes referred to as the vector of long-run parameters. We can also normalize equation (4) with respect to $\beta_{i 2}$,

$$
\begin{aligned}
& \text { POIL }_{t}= \theta_{i 1}+\theta_{i 2} \text { FPOIL }_{i t}+\theta_{i 3} E X_{t}+\theta_{i 4} \text { WELLS }_{t} \\
&+\theta_{i 5} \text { DOIL }_{t}+\theta_{i 6} \text { SOIL }_{t}+\theta_{i 7} \text { IRAQ }_{t}+\eta_{i t} \\
& \theta_{i j}=-\frac{\beta_{i j}}{\beta_{i 2}} \quad \eta_{i t}=-\frac{v_{i t}}{\beta_{i 2}}
\end{aligned}
$$

Since all of the variables are in natural logarithmic units, the $\theta_{i j}$ and their estimates are elasticity coefficients and may be interpreted as the percentage change in the price of oil given a one percent change in the relevant explanatory variable, ceteris paribus. Moreover, the magnitude of the elasticities will tell us which variables have had the largest effect on the price of crude over this period.

\section{RESULTS}

We first test each variable for the presence of a unit root using the more efficient Dickey Fuller Test with GLS Detrending (Elliot, Rothenberg, and Stock (1996)). The results are in Table 1 . The null hypothesis of a unit root cannot be rejected for each and it appears that the variables are all integrated of order one (I(1)).

Table 1

Unit Root Tests

Variable

Dickey-Fuller Tests with GLS Detrending

POIL $_{t}$ - Crude Oil Spot Price at Cushing, Oklahoma $H_{0}$ : Series has a Unit Root - "t" statistic

(adjusted for inflation using the Personal Consumption Expenditure Chain Price Index)

FPOIL $_{i t}$ - Two, Three, Four, and Six Months

Futures Price of Light, Sweet Crude Oil ( $i=2,3,4,6)$ $-.492,-.618,-.242,-.312$

$E X_{t}$ - Real Trade Weighted Exchange Value of Dollar $-.899$ versus Major Currencies

WELLS $S_{t}$ - Total Oil from New U.S. Wells

DOIL $_{t}$ - World Oil Demand

$S O I L_{t}$ - World Oil Supply 
As noted above, there are four futures price variables: two months, three months, four months, and six months contracts. This means that there are four models estimated using each futures price variable $(i=2,3,4,6)$. We determined the lag length, $p$, by fitting the VAR equation (1) for each model and using the lag length criteria test in Eviews

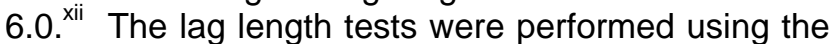
likelihood ratio test statistic recommended by Sims (1980). ${ }^{\text {iii }}$ Following this, the Johansen procedure (Johansen (1988)) was used to test for cointegration and the results may be found in Table 2 . It is interesting to note that the null hypothesis of $r=0$ is rejected in favor of the alternative that $r=1$ in each case. However, in the models with the shorter two and three months contracts, there is some ambiguity regarding the number of cointegrating relationships at $\alpha=.05$ ( $r=3$ and $r=2$, respectively), albeit the null hypothesis that $r=0$ is rejected in each case at $\alpha=.01$. When there are multiple cointegrating vectors, it is not straightforward to interpret their meaning, since you have to know what restrictions should be imposed on the system. Given the rejection of the null hypothesis that $r=0$ in each case at the .01 level, we shall proceed to estimate the VEC equation (3) and equation (5) for each futures price.

Table 2

$$
\begin{aligned}
& H_{0}: \operatorname{Rank}\left(\pi_{i}\right)=r \\
& H_{A}: \operatorname{Rank}\left(\pi_{i}\right)=r+1
\end{aligned}
$$

\section{Johansen Cointegration Tests} Maximum Eigenvalue Test

\begin{tabular}{|c|c|c|c|c|}
\hline $\begin{array}{l}\text { Hypothesized } \\
\text { No. of CE(s) }\end{array}$ & Eigenvalue & $\begin{array}{c}\text { Max-Eigen } \\
\text { Statistic }\end{array}$ & $\begin{array}{c}5 \text { Percent } \\
\text { Critical Value }\end{array}$ & $\begin{array}{c}1 \text { Percent } \\
\text { Critical Value }\end{array}$ \\
\hline None ** & 0.199033 & 53.48658 & 45.28 & 51.57 \\
\hline At most 1 * & 0.170095 & 44.93289 & 39.37 & 45.10 \\
\hline At most $2^{\star *}$ & 0.150309 & 39.25458 & 33.46 & 38.77 \\
\hline At most 3 & 0.091173 & 23.03964 & 27.07 & 32.24 \\
\hline At most 4 & 0.062096 & 15.45000 & 20.97 & 25.52 \\
\hline At most 5 & 0.021932 & 5.344337 & 14.07 & 18.63 \\
\hline At most 6 & 0.000600 & 0.144706 & 3.76 & 6.65 \\
\hline
\end{tabular}

1. Model using two months contract futures price:

Max-eigenvalue test indicates 3 cointegrating equation(s) at the $5 \%$ level Max-eigenvalue test indicates 1 cointegrating equation(s) at the $1 \%$ level $\left.{ }^{*}{ }^{* \star}\right)$ denotes rejection of the hypothesis at the $5 \%(1 \%)$ level

\begin{tabular}{|c|c|c|c|c|}
\hline $\begin{array}{c}\text { Hypothesized } \\
\text { No. of CE(s) }\end{array}$ & Eigenvalue & $\begin{array}{c}\text { Max-Eigen } \\
\text { Statistic }\end{array}$ & $\begin{array}{c}5 \text { Percent } \\
\text { Critical Value }\end{array}$ & $\begin{array}{c}1 \text { Percent } \\
\text { Critical Value }\end{array}$ \\
\hline None ** & 0.208862 & 56.69632 & 45.28 & 51.57 \\
\hline At most 1 * & 0.157357 & 41.43334 & 39.37 & 45.10 \\
\hline At most 2 & 0.116121 & 29.87119 & 33.46 & 38.77 \\
\hline At most 3 & 0.079595 & 20.07181 & 27.07 & 32.24 \\
\hline At most 4 & 0.048214 & 11.95842 & 20.97 & 25.52 \\
\hline At most 5 & 0.024076 & 5.897672 & 14.07 & 18.63 \\
\hline At most 6 & $6.38 \mathrm{E}-05$ & 0.015439 & 3.76 & 6.65 \\
\hline
\end{tabular}

2. Model using three months contract futures price:

Max-eigenvalue test indicates 2 cointegrating equation(s) at the $5 \%$ level Max-eigenvalue test indicates 1 cointegrating equation(s) at the $1 \%$ level $\left.{ }^{*}{ }^{\star *}\right)$ denotes rejection of the hypothesis at the $5 \%(1 \%)$ level 
Am. J. Soc. Mgmt. Sci., 2010, 1(1): 13-23

3. Model using four months contract futures price:

\begin{tabular}{ccccc}
\hline \hline $\begin{array}{c}\text { Hypothesized } \\
\text { No. of CE(s) }\end{array}$ & Eigenvalue & $\begin{array}{c}\text { Max-Eigen } \\
\text { Statistic }\end{array}$ & $\begin{array}{c}0.05 \\
\text { Critical Value }\end{array}$ & Prob. ${ }^{* *}$ \\
\hline None * & 0.213405 & 58.09017 & 46.23142 & 0.0018 \\
At most 1 & 0.151167 & 39.66196 & 40.07757 & 0.0556 \\
At most 2 & 0.118609 & 30.55358 & 33.87687 & 0.1185 \\
At most 3 & 0.084249 & 21.29855 & 27.58434 & 0.2586 \\
At most 4 & 0.046635 & 11.55736 & 21.13162 & 0.5917 \\
At most 5 & 0.024469 & 5.995163 & 14.26460 & 0.6138 \\
At most 6 & $4.76 E-06$ & 0.001152 & 3.841466 & 0.9723 \\
\hline \hline
\end{tabular}

Max-eigenvalue test indicates 1 cointegrating eqn(s) at the 0.05 level

* denotes rejection of the hypothesis at the 0.05 level

4. Model using six months contract futures price:

\begin{tabular}{|c|c|c|c|c|}
\hline $\begin{array}{l}\text { Hypothesized } \\
\text { No. of CE(s) }\end{array}$ & Eigenvalue & $\begin{array}{c}\text { Max-Eigen } \\
\text { Statistic }\end{array}$ & $\begin{array}{c}0.05 \\
\text { Critical Value }\end{array}$ & Prob.** \\
\hline None * & 0.205918 & 55.79766 & 46.23142 & 0.0036 \\
\hline At most 1 & 0.142071 & 37.08252 & 40.07757 & 0.1047 \\
\hline At most 2 & 0.117888 & 30.35563 & 33.87687 & 0.1244 \\
\hline At most 3 & 0.085598 & 21.65541 & 27.58434 & 0.2386 \\
\hline At most 4 & 0.047838 & 11.86289 & 21.13162 & 0.5613 \\
\hline At most 5 & 0.024614 & 6.031163 & 14.26460 & 0.6092 \\
\hline At most 6 & $3.05 E-05$ & 0.007375 & 3.841466 & 0.9311 \\
\hline
\end{tabular}

Max-eigenvalue test indicates 1 cointegrating eqn(s) at the 0.05 level

* denotes rejection of the hypothesis at the 0.05 level

The estimation results for equation (5) are in Table 3. Since our predominant interest lies with the cointegrating relation, for reasons of brevity, the estimates of the entire VEC model are not presented here. ${ }^{\mathrm{xiv}}$ The initial most noteworthy result is the increasing magnitude and statistical significance of the futures price coefficients for each of the equations in Table 3,

\section{Coefficient}

- Two Months Contract:

- Three Months Contract:

1.100

- Four Months Contract:

1.186

- Six Months Contract:

1.565

A one percent increase in the shorter-term two and three-months contracts is associated with a close to one percent increase in the real price of crude-a proportionate or unitary elastic response. However, a one percent increase in the six-months contract futures price is associated with a 1.6 percent increase in the real price of oil-a more than proportionate or elastic response. What is even more interesting is the magnitude of the coefficients of the remaining variables as the contract length increases. For example, in the equations for the two, three, and four months contracts futures prices, the predominant variable in terms of its effect on the real price of oil is world supply,

\section{Coefficient on Supply Variable}

$\begin{array}{ll}\text { - Two Months Contract: } & -3.180 \\ \text { - Three Months Contract: } & -2.094 \\ \text { - Four Months Contract: } & -1.916\end{array}$

Thus, for these shorter-term futures prices, one could argue that "the economic data show that oil price levels are being driven by powerful fundamental economic forces and the laws of supply and demand," not by speculation. ${ }^{\mathrm{xv}}$ Changes in shorterterm futures prices are not unimportant in predicting oil prices levels but changes in supply have a larger effect on real oil prices. ${ }^{\text {xi }}$ 
Am. J. Soc. Mgmt. Sci., 2010, 1(1): 13-23

Table 3

\begin{tabular}{|c|c|c|c|c|}
\hline \multirow[b]{2}{*}{ Variable } & \multicolumn{4}{|c|}{$\begin{array}{c}\text { Cointegration Estimation Results } \\
\text { Fstimated Cofficients }\end{array}$} \\
\hline & Two-Months & Three Months & Four Months & Six Months \\
\hline $\mathrm{POIL}_{t}$ & 1 & 1 & 1 & 1 \\
\hline \multirow[t]{2}{*}{ FPOIL $_{i t}$} & .920 & 1.10 & 1.186 & 1.565 \\
\hline & $(30.84)^{\star *}$ & $(24.27)^{\star \star}$ & $(19.475)^{\star \star}$ & $(12.596)^{\star \star}$ \\
\hline \multirow[t]{2}{*}{$E X_{t}$} & .070 & -.182 & -.240 & -.430 \\
\hline & $(1.28)$ & $(-2.06)^{\star}$ & $(-1.994)^{\star}$ & $(-1.718)$ \\
\hline \multirow[t]{2}{*}{$W E L L S_{t}$} & -.084 & .020 & -.012 & -.152 \\
\hline & $(-3.83)^{\star \star}$ & $(.567)$ & $(-.254)$ & $(-1.582)$ \\
\hline \multirow[t]{2}{*}{$\mathrm{DOIL}_{t}$} & 1.97 & .129 & .405 & 3.128 \\
\hline & $(4.06)^{\star \star}$ & $(.165)$ & $(.378)$ & $(1.391)$ \\
\hline \multirow[t]{2}{*}{$S O I L_{t}$} & -3.18 & -2.094 & -1.916 & -.596 \\
\hline & $(-7.32)^{\star \star}$ & $(-2.992)^{\star \star}$ & $(-1.999)^{*}$ & $(-.298)$ \\
\hline$I R A Q_{t}$ & .035 & -.008 & .043 & .199 \\
\hline Intercept & $\begin{array}{l}(1.54) \\
4.65\end{array}$ & $\begin{array}{l}(-.233) \\
7.246\end{array}$ & $\begin{array}{l}(.889) \\
8.459\end{array}$ & $\begin{array}{l}(1.962)^{\star} \\
13.386\end{array}$ \\
\hline
\end{tabular}

However, the situation is different for the six months contract futures price. Not only is the coefficient on the six-months futures price elastic and statistically significant, but it is the only statistically significant variable (other than the Iraq war dummy variable) in the equation. In one sense, this is not a surprising finding given that fact that a six months futures contract would be inherently more speculative than the shorter contract periods. Therefore, the six months futures price, not supply nor demand, appears to be driving the real price of oil in the market, ceteris paribus. These results imply that if the six months futures price were to fall by twenty percent, the real price of crude would decline by more than thirty percent from its present-day levels.

\section{CONCLUSION}

We have found that for model specifications that include shorter-term futures contracts, supply does indeed dominate price movements in the crude oil market. However, for longer-term contracts, the real price of oil appears to be determined principally by the futures price. In order for the relationship between futures prices and the market price of oil outlined above to be valid, two associations would have to exist: futures prices and inventories would have to be positively cointegrated and supply and inventories would have to be inversely cointegrated.
As mentioned previously, the only way futures prices/speculation can increase oil prices is through hoarding which would increase inventories and remove oil from the market. There is empirical evidence of hoarding in the crude oil market. The estimation results of the following equations may be found in Tables 4 and 5 ,

$$
\begin{aligned}
& \text { STOCKS }_{t}=\gamma_{1}+\gamma_{2} \text { FPOIL }_{6 t}+\gamma_{3} \text { DOIL }_{t}+\gamma_{4} \text { SOIL }_{t}+\xi_{t}, \\
& \text { SOIL }_{t}=\varphi_{1}+\varphi_{2} \text { STOCKS }_{t}+\tau_{t},
\end{aligned}
$$

where the variable $S T O C K S_{t}$ is U.S. stocks of crude oil excluding the Strategic Petroleum Reserve. It is important to note that the six months futures price is positively and significantly related to inventories with an elasticity coefficient of .135 and oil stocks are inversely and significantly related to market supply with a coefficient of 3.82. Thus, a ten percent increase in the six month futures price is associated with 1.35 percent increase in inventories which is in turn associated with a decrease in oil supplies of 5.16 percent. While this may not appear to be a large percentage, consider that fact that in January 2004 the six months futures contract settlement price for WTI/Light Crude was $\$ 31.39$ per barrel and in January 2008 it was $\$ 91.10$ per barrel--a 190 percent increase. In addition to the above empirical analysis, it is possible to discern graphically from 
Figure 3 that there was a slight increase in oil inventories with a concomitant "leveling-off" of supply after 2005-indicating that perhaps some of the more current precipitous oil price increases are indeed due to speculation (shaded yellow area in Figure 3).

\section{Table 4}

Cointegration and VEC Estimation Results

Six Months Futures Price and U.S. Inventories

1. Johanson Cointegration Test:

\begin{tabular}{|c|c|c|c|c|}
\hline Hypothesized & & Max-Eigen & 0.05 & \\
\hline No. of CE(s) & Eigenvalue & Statistic & Critical Value & Prob. ** \\
\hline None * & 0.105006 & 29.50957 & 27.58434 & 0.0280 \\
\hline At most 1 & 0.052065 & 14.22294 & 21.13162 & 0.3470 \\
\hline At most 2 & 0.022287 & 5.995269 & 14.26460 & 0.6138 \\
\hline At most 3 & 0.000175 & 0.046592 & 3.841466 & 0.8291 \\
\hline
\end{tabular}

Max-eigenvalue test indicates 1 cointegrating eqn(s) at the 0.05 level

* denotes rejection of the hypothesis at the 0.05 level

2. Estimated Cointegration Vector:

Variable Estimated Coefficients (t Statistics Below in Parenthesis)

$\begin{array}{ll}\text { STOCKS }_{t} & 1 \\ \text { FPOIL }_{6 t} & .135 \\ & (3.696)^{\star \star} \\ \text { DOIL }_{t} & -2.980 \\ & (-2.625)^{\star \star} \\ \text { SOIL }_{t} & 1.886 \\ & (1.880)\end{array}$

** - statistically significant at $\alpha=.01$ 
Am. J. Soc. Mgmt. Sci., 2010, 1(1): 13-23

Table 5

Cointegration and VEC Estimation Results

Supply and U.S. Oil Inventories

1. Johanson Cointegration Test:

\begin{tabular}{|c|c|c|c|c|}
\hline Hypothesized & & Max-Eigen & 0.05 & \\
\hline No. of CE(s) & Eigenvalue & Statistic & Critical Value & Prob.** \\
\hline None * & 0.173906 & 52.72903 & 15.89210 & 0.0000 \\
\hline At most 1 & 0.023577 & 6.585256 & 9.164546 & 0.1501 \\
\hline
\end{tabular}

Max-eigenvalue test indicates 1 cointegrating eqn(s) at the 0.05 level

* denotes rejection of the hypothesis at the 0.05 level

2. Estimated Cointegration Vector:

Variable Estimated Coefficients (t Statistics Below in Parenthesis)

$\mathrm{SOIL}_{t} \quad 1$

STOCKS $_{t} \quad-3.820$

$(-3.259)^{\star \star}$

** - statistically significant at $\alpha=.01$

Figure 3

Stocks of Crude Oil vs. Oil Supplies

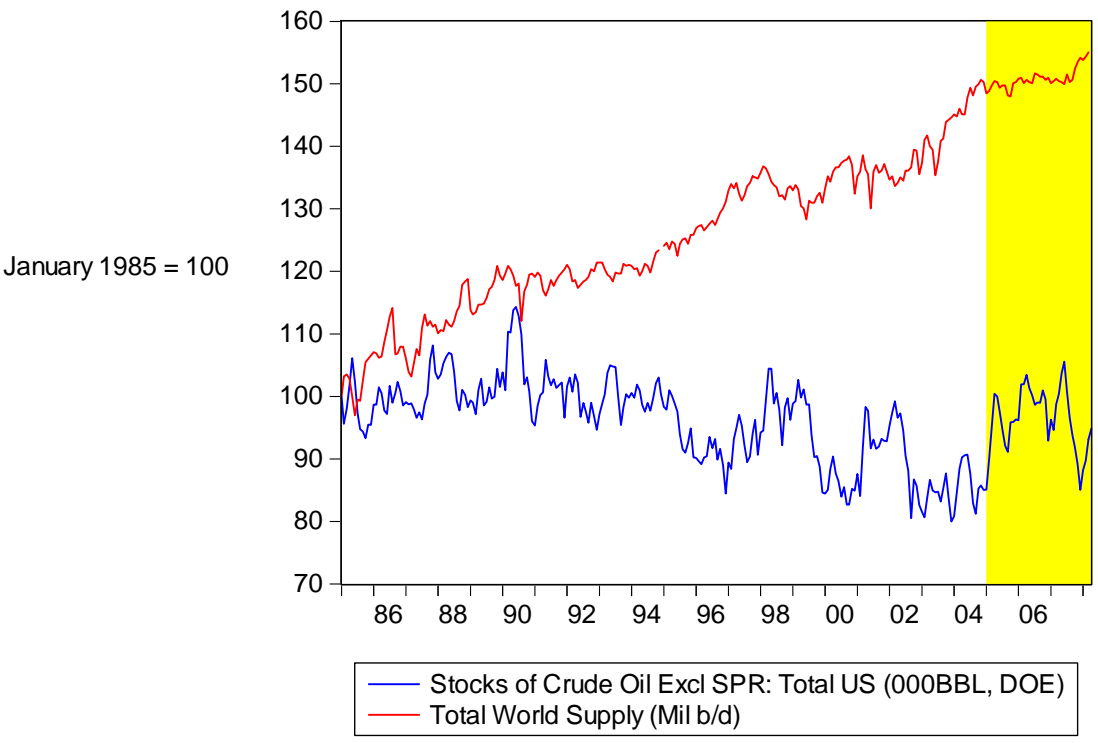

From a policy perspective and given the current Congressional Hearings on the role of speculation in rising oil prices, the results of this analysis indicate that if regulators really wanted to limit speculation in the oil market, they could keep the shorter-term 
futures contracts and eliminate the more speculative six months futures contracts.

\section{REFERENCES}

Elliott, Graham, Thomas J. Rothenberg and James $\mathrm{H}$. Stock (1996). Efficient Tests for an Autoregressive Unit Root, Econometrica, 64, pp. 813-836.

Enders, Walter (2004). Applied Econometric Time Series, Second Edition, John Wiley and Sons, Inc.: New York, NY.

Engle, Robert E., and Clive W.J. Granger (1987). Cointegration and Error-Correction: Representation,
Estimation, and Testing, Econometrica, 55, March, pp. 251-276.

Johansen, Soren (1988). Statistical Analysis of Cointegration Vectors, Journal of Economic Dynamics and Control, 12, June-September, pp. 231-254.

Krugman, Paul (2008). The Oil Nonbubble, The New York Times Opinion, http://www.nytimes.com/2008/05/12/opinion/12krugma n.html? $r=2 \&$ th\&emc=th\&oref=sl\&oref=slogin.

Sims, Christopher (1980). Macroeconomics and Reality, Econometrica, 48, January, pp. 161-200.

\section{ENDNOTES}

'Spot Price of WTI/Light Crude as traded on the New York Mercantile Exchange for delivery in Cushing, Oklahoma.

ii Ibid.

iii Paul Krugman, The Oil Nonbubble, The New York Times Opinion, http://www.nytimes.com/2008/05/12/opinion/12krugman.html? r=2\&th\&emc=th\&oref=sl\&oref=slogin

${ }^{i v}$ http://www.latimes.com/business/la-fi-petruno24-2008may24,1,6762856.column.

${ }^{v}$ Ibid

vi Ibid

vii Ibid

viii Ibid

${ }^{\text {ix }}$ Spot Price of WTI/Light Crude as traded on the New York Mercantile Exchange for delivery in Cushing, Oklahoma.

${ }^{\times}$http://www.finfacts.com/irelandbusinessnews/publish/article 10004190.shtml.

${ }^{x i}$ Ibid

${ }^{\mathrm{xii}}$ EViews 6.0 was the software that was used for this entire analysis.

xiii See Enders (2004), page 363 for a complete explanation of the procedure. For reasons of brevity, the results will be made available upon request from the authors.

xiv See Enders (2004), page 363 for a complete explanation of the procedure. For reasons of brevity, the results will be made available upon request from the authors.

${ }^{x v}$ http://www.latimes.com/business/la-fi-petruno24-2008may24,1,6762856.column.

xvi We should note that the elasticity coefficient on futures price for each equation is the second largest (after supply) in the two, three, and four months model (Table III). 